\title{
Stabilność oksydacyjna estrów metylowych kwasów tłuszczowych stanowiących samoistne paliwo lub biokomponent olejów napędowych
}

\begin{abstract}
Stabilność oksydacyjna jest jedną z podstawowych właściwości eksploatacyjnych, która jest oznaczana dla paliw stosowanych do zasilania silników z zapłonem samoczynnym. Wprowadzenie na rynek nowego rodzaju paliwa pochodzenia roślinnego, estrów metylowych kwasów tłuszczowych (FAME) oraz oleju napędowego pochodzenia naftowego z pewnym udziałem biokomponentów (obecnie do 7\% $(V / V)$ ), ze względu na odmienny skład chemiczny, spowodowało trudności zarówno w utrzymaniu odpowiedniego poziomu stabilności na utlenianie, jak również w samej jej ocenie. Zmiany te wymusiły z kolei na producentach paliw stosowanie pakietu dodatków uszlachetniających, których skład musiał zostać wzbogacony o przeciwutleniacz tak, aby było możliwe utrzymanie wymaganego poziomu stabilności paliwa w czasie całego łańcucha dystrybucji (od momentu wyprodukowania paliwa do ostatecznego użytkownika).
\end{abstract}

Słowa kluczowe: stabilność oksydacyjna, FAME, dodatki przeciwutleniające.

\section{Oxidation stability of fatty acid methyl esters as a B100 fuel or as a biocomponent of diesel fuels}

Oxidation stability is one of the basic operating properties which is determined for fuels used in diesel engines. The introduction on the market of a new type of fuel of vegetable origin, fatty acid methyl esters (FAME) and diesel fuels with a certain share of biocomponents (currently up to $7 \%(V / V)$ ), due to their different chemical composition has caused difficulties, both in maintaining an adequate level of oxidation stability, and in its assessment. These changes obliged fuel producers to use a package of additives that had to be enriched with antioxidants to maintain the required level of fuel stability throughout the entire distribution chain (from the production of the fuel to the end user).

Key words: oxidtaion stability, FAME, antioxidation additives.

Na skutek rosnących wymagań wobec silników spalinowych oraz rozwoju przemysłu rafineryjnego, w latach dwudziestych XX wieku rozpoczęło się zainteresowanie dodatkami do paliw silnikowych. W pierwszych latach rozwoju technologii produkcji olejów napędowych zwracano głównie uwagę na parametry, takie jak zimny rozruch oraz jakość zapłonu. Jednym z pierwszych (stosowany od lat dwudziestych XIX wieku do dziś) dodatków stosowanych do oleju napędowego był dodatek poprawiający zapłon. Popyt na oleje napędowe wzrastał w bardzo szybkim tempie, a wprowadzenie dodatków poprawiających przepływ w niskich temperaturach w latach siedemdziesiątych XX wieku było punktem zwrotnym w dostępności tego produktu. Przed ich wprowadzeniem do formulacji paliwa, niemożliwe było zasilanie olejem napędowym pojazdów w okresach zimowych lub generowało to bardzo duże koszty związane z modyfikacją technologii jego produkcji. W latach osiemdziesiątych ub. wieku przejście na pakiety dodatków uszlachetniających odbiło się na produkcji bardziej wyrafinowanych produktów rafineryjnych, wtym również olejów napędowych. W ostatnim czasie legislacja związana z ochroną środowiska wymusiła wprowadzenie dodatków ograniczających powstawanie osadów, które odkładają się na elementach silnika, przyczyniając się między innymi do wzrostu emisji szkodliwych substancji w spalinach oraz do wzrostu zużycia paliwa w czasie eksploatacji. Wprowadzenie niskosiarkowych paliw wymusiło na producentach konieczność wprowadzenia do pakietu dodatków smarnościowych i zastosowanie nowych dodatków, poprawiających odporność na utlenianie. Z kolei obowiązujące od 2009 roku dyrektywy Parlamentu Europejskiego i Rady FQD oraz RED, narzuciły 
konieczność stosowania do oleju napędowego nowego komponentu, pochodzącego ze źródeł odnawialnych - estrów metylowych kwasów tłuszczowych. Przyczyniło się do ograniczenia stosowania dodatków smarnościowych lub wręcz do całkowitej ich eliminacji ze składu pakietu dodatków uszlachetniających, ale jednocześnie spowodowało wzrost problemów związanych ze stabilnością oksydacyjną finalnego produktu. Jako dodatki przeciwutleniające do oleju napędowego stosuje się związki organiczne rozpuszczalne w paliwie, zawierające w swej strukturze grupy fenolowe lub grupy aminowe (np. rozgałęzione alkilofenole i aromatyczne diaminy).

Nieustannie rosnące światowe zainteresowanie wykorzystaniem surowców biologicznych jako paliw silnikowych wiąże się z prognozami wskazującymi na systematyczne wyczerpywanie się złóż ropy naftowej oraz obserwowanymi skutkami zwiększającej się emisji gazów cieplarniach. Zwłaszcza rośnie zastosowanie FAME jako komponentu oleju napędowego, jednak należy tu zwrócić uwagę na to, że charakter biopaliw w zasadniczy sposób różni się od właściwości zastępowanych, konwencjonalnych paliw węglowodorowych [16, 21]. Oprócz cech niewątpliwie korzystnych, takich jak: zmniejszenie wprowadzania do obiegu gazów cieplarnianych w porównaniu do węglowodorowych źródeł nieodnawialnych, zużycie nadmiaru produkowanych tłuszczów roślinnych i zwierzęcych, poprawa smarności paliw i obniżanie poziomu emisji tlenku węgla, niespalonych węglowodorów czy cząstek stałych emitowanych z silników Diesla, obserwuje się szereg zjawisk niekorzystnych, w tym: podwyższenie emisji tlenków azotu, rosnącą tendencję do tworzenia żywic, laków i osadów na elementach silnika, zwiększenie częstości wymiany elementów mechanicznych, np. filtrów paliwa, a także pojawienie się zjawisk niekompatybilności niektórych materiałów (tworzywa sztuczne) w systemie paliwowym. Quigley [16] przedstawił podstawowe problemy związane z wykorzystaniem FAME: problemy niskotemperaturowe, pienienie, trudności przy wydzielaniu wody, a także niską stabilność oksydacyjną, tworzenie osadów i laków na wtryskiwaczach oraz zwiększenie korozyjności paliwa [14].

Podstawową różnicą paliw konwencjonalnych i biopaliw jest polarność układu związana z obecnością heteroatomów tlenu. Estry metylowe kwasów tłuszczowych (FAME), stosowane jako zamiennik bądź komponent oleju napędowego, są szczególnym rodzajem estrów - pochodnymi kwasów tłuszczowych i metanolu. W ich budowie występują trzy elementy strukturalne wyjątkowo podatne na różne reakcje chemiczne, są to allilowe atomy wodoru $-\mathrm{CH}-\mathrm{C}=\mathrm{C}-$, wiązania podwójne $-\mathrm{C}=\mathrm{C}-\mathrm{i}$ grupy estrowe $-\mathrm{COOCH}_{3}$. Już wcześniej stwierdzono [7], że woda w obecności powietrza może oddziaływać z wyżej wspomnianymi strukturami. Zatem można przypuszczać, że wprowadzeniu do kompozycji paliwowej pakie- tów dodatków zawierających substancje aktywne o polarnym charakterze (np. amidy, imidy, azotany, aminy, alkohole, etery) mogą towarzyszyć reakcje chemiczne, mające wpływ na właściwości użytkowe paliwa. Wiązania podwójne są podatne na reakcje addycji, utlenienia i polimeryzacji, allilowe atomy wodoru łatwo ulegają reakcjom rodnikowym (utlenianie, polimeryzacja), natomiast grupy estrowe mogą podlegać hydrolizie i/lub transestryfikacji. Dodatkowo kwaśne protony, przyłączone do atomów węgla estrów, są podatne w odpowiednich warunkach na inne reakcje, np. typu kondensacji aldolowej, tworząc b-ketoestry [12].

Stabilność paliw jest to odporność paliwa na procesy degradacji, która może zmieniać jego właściwości i w wyniku której mogą tworzyć się niepożądane substancje. Paliwo uważa się za niestabilne wówczas gdy ulega z łatwością takim zmianom. Proces degradacji może przebiegać według różnych mechanizmów [17]:

- utlenianie lub autoutlenianie poprzez kontakt z tlenem w temperaturze pokojowej,

- termiczna lub termoooksydacyjna dekompozycja pod wpływem ogrzewania,

- hydroliza na skutek kontaktu z wodą lub wilgocią, obecną w zbiornikach i rurociągach,

- skażenie mikrobiologiczne poprzez zanieczyszczenia i wodę, które mogą przenosić bakterie i grzyby [7].

Stabilność oksydacyjna odnosi się do tendencji paliwa do reakcji z tlenem w temperaturze zbliżonej do temperatury pokojowej i określa relatywną podatność paliwa na degradację w wyniku procesu utleniania. Reakcje te są znacznie wolniejsze niż te, które przebiegają w wyższych temperaturach. Stopień degradacji na skutek reakcji utleniania biodiesla w silniku będzie spowodowany wieloma czynnikami, między innymi rodzajem surowca, z którego otrzymano estry, sposobem ich produkcji, zastosowanymi dodatkami do paliw, obecnością zanieczyszczeń, sposobem i warunkami przechowywania, jak również rodzajem zbiornika, w którym jest przechowywane paliwo oraz rodzajem systemu dystrybucji $[17,18]$.

Stabilność termiczna to podatność na degradację paliwa na skutek oddziaływania podwyższonej temperatury, znacznie wyższej niż temperatura pokojowa, i ma znaczenie dla zużycia biodiesla, ponieważ wysokie temperatury paliwa mogą wystąpić w warunkach napotykanych w systemach wtrysku paliwa, gdy jest ono zawracane przez układ przelewowy systemu wtryskowego z powrotem do zbiornika paliwa $[17,31]$.

Stabilność w czasie magazynowania odnosi się do ogólnej stabilności paliwa w czasie długotrwałego przechowywania. Degradacja na skutek procesów utleniania jest prawdopodobnie jednym z podstawowych czynników wpływających na stabilność w czasie magazynowania. Może ona zależeć również od zawartości wody i skażenia mikrobiologicznego [28]. 
Woda może wspomagać rozwój życia biologicznego, prowadzić do korozji zbiorników, uczestniczyć w procesie tworzenia emulsji, jak również powodować hydrolizę lub utlenianie hydrolityczne $[2,31]$.

Biodiesel jest mniej odporny na utlenianie niż olej napędowy niezawierający biokomponentu, a ta cecha jest jedną z ważniejszych właściwości estrów metylowych kwasów tłuszczowych i wpływa na jakość tego paliwa, głównie w czasie wydłużonego przechowywania. Degradacja na skutek procesu utleniania powoduje powstawanie produktów reakcji, które mogą pogorszyć właściwości paliwa, jego jakość oraz sprawność silnika. A zatem odporność na utlenianie jest ważną kwestią, którą należy uwzględniać w prowadzonych badaniach $[12,25,29]$.

W ostatnich latach poziom komercyjnej produkcji biodiesla w Unii Europejskiej gwałtownie wzrósł. Normalizacja oraz zapewnienie odpowiedniej jakości paliwa są kluczowymi czynnikami dopuszczenia na rynek, jak również stabilność w czasie magazynowania jest jednym z głównych czynników zapewnienia jakości. Paliwa niespełniające tych samych standardów jakości charakteryzują się wysokim stopniem zmienności właściwości paliwowych oraz w późniejszym czasie wpływają na osiągi silnika. $Z$ tego też względu konieczne było wprowadzenie rygorystycznej normy, uwzględniającej parametry jakościowe oleju napędowego. Degradacja na skutek procesu utleniania oleju napędowego zawierającego FAME może prowadzić do formowania się kwasów, nierozpuszczalnych osadów i depozytów typu varnish [19]. Właściwości paliwa mogą ulec w znacznym stopniu pogorszeniu. Nierozpuszczalne osady mogą zatykać przewody i filtry paliwowe. Substancje, powodujące korozję lub osadzanie się osadów, mogą wpływać na uszkodzenie lub pogorszenie współdziałania części silnika i prowadzić do problemów z obsługą. Pomimo tego, że degradacja biodiesla z powodu niestabilności oksydacyjnej jest niekorzystna, może być również korzystna ze względów środowiskowych, ponieważ oznacza to, że biodiesel ulega łatwej biodegradacji [2, 22].

Biodiesel otrzymywany jest $\mathrm{z}$ olejów roślinnych, thuszczów zwierzęcych lub zużytych olejów posmażalniczych. Estry metylowe kwasów thuszczowych otrzymywane z tych surowców, zawierają mono- i poli- nienasycone łańcuchy kwasów tłuszczowych, co powoduje wzrost ich podatności na utlenianie. Jednym z głównych problemów technicznych podczas eksploatacji biodiesla jest jego podatność na utlenianie pod wpływem ekspozycji na działanie tlenu z powietrza. Ta podatność jest wynikiem obecności nienasyconych łańcuchów kwasów tłuszczowych, zwłaszcza z bis-allilowych grup metylenowych. Utlenianie łańcuchów kwasów tłuszczowych jest złożonym procesem, który może przebiegać według różnych mechanizmów $[6,13]$.
Zwykle FAME otrzymuje się w reakcji kwasów z alkoholami lub fenolami, podczas której wydziela się cząsteczka wody. FAME są szczególnym rodzajem estrów, powstających w wyniku transestryfikacji olejów roślinnych lub zwierzęcych w środowisku metanolu. W ich budowie występują trzy elementy strukturalne podatne na różne reakcje chemiczne, są to allilowe atomy wodoru, wiązania podwójne i grupy estrowe.

Wiązania podwójne są podatne na reakcje addycji, utlenienia i polimeryzacji, allilowe atomy wodoru łatwo ulegają reakcjom rodnikowym (utlenianie, polimeryzacja), natomiast grupy estrowe powinny ulegać hydrolizie.

Proces starzenia paliwa jest przyspieszany w wyniku działania podwyższonej temperatury, tlenu, wody, jonów metali i innych zanieczyszczeń oraz obecności mikroorganizmów. Obecność niskocząsteczkowych kwasów oraz aldehydów obniża temperaturę zapłonu, natomiast obecność kwasów (głównie kwasu mrówkowego i octowego) zwiększa liczbę kwasową. Ponadto w utlenionym biodieslu znajdują się polimery, często klasyfikowane do osadów, laków i pozostałości, które mogą prowadzić do blokowania filtrów i awarii wtryskiwaczy $[9,10,12,28]$.

Na zdolność do utleniania FAME oraz ich mieszanin z ON wpływa zatem:

- stopień nienasycenia związków wchodzących w skład mieszaniny - im więcej związków nienasyconych, tym szybciej paliwo będzie się utleniać,

- temperatura, promienie słoneczne i dostęp do tlenu przyspieszają reakcje oksydacji, więc przechowywanie mieszanin FAME z ON w jasnych pojemnikach i w ciepłych pomieszczeniach nie jest wskazane,

- niektóre metale jak: miedź, mosiądz, brąz, ołów, cyna, cynk, mogą przyspieszać proces degradacji i tworzyć jeszcze większe ilości produktów utleniania.

Olej napędowy z biokomponentami nie powinien być przechowywany przez dłuższy czas w systemach zawierających te metale. Dodatki chelatujące metale, które służą do ich dezaktywacji, mogą zmniejszyć lub wyeliminować negatywne skutki ich obecności; niektóre rodzaje obróbki surowca i przetwarzania estrów mogą usunąć naturalne przeciwutleniacze, potencjalnie zmniejszając stabilność paliwa. Charakter rodników oraz geometria wiązania podwójnego mają również wpływ na produkty utleniania.

Szybkość utleniania nienasyconych kwasów tłuszczowych lub estrów może znacznie się różnić. Zrozumienie procesu utleniania jest skomplikowane ze względu na to, że kwasy tłuszczowe z reguły występują w postaci złożonych mieszanin, których głównymi składnikami/komponentami są substancje katalizujące lub hamujące go. Obserwacja ta dotyczy biodiesla, ponieważ zawiera on zwykle znaczne ilości estrów kwasu oleinowego, linolowego i linolenowego, mogące wpływać na proces utleniania [13]. 
Szczególnie podatne na tworzenie rodników są atomy węgla sąsiadujące $z$ wiązaniami podwójnymi, a zwłaszcza leżące pomiędzy nimi. Utworzenie rodnika allilowego, sprzężonego z jednym wiązaniem podwójnym, wymaga nakładu energii mniejszego niż utworzenie niesprzężonego rodnika na grupie metylenowej o około $40 \mathrm{~kJ} / \mathrm{mol}$, a rodnika sprzężonego z dwoma wiązaniami podwójnymi aż o około $120 \mathrm{~kJ} / \mathrm{mol}$. Tłumaczy to znaczną podatność na reakcje utleniania pochodnych kwasów zawierających dwa wiązania podwójne.

$Z$ efektem rezonansowym związane są również przekształcenia geometrii cząsteczek. W przypadku kwasu linolowego z wiązaniem cis pomiędzy 9 i 10 atomem węgla po utworzeniu rodnika allilowego na atomie węgla 8 lub $11 \mathrm{w}$ wyniku jego dalszych reakcji wiązanie ulega przesunięciu pomiędzy $8 \div 9$ lub $10 \div 11$ atom węgla ze zmianą konfiguracji na trans.

W przypadku kwasu linolenowego sytuacja jest bardziej złożona, analiza struktur rezonansowych rodnika allilowego, powstającego się po oderwaniu wodoru od atomu węgla $\mathrm{C}_{8}$, wskazuje na tworzenie się układów sprzężonych wiązań cis-trans w produktach końcowych utleniania.

Przedstawione powyżej przykłady tworzenia rodników w wyniku reakcji utleniania, w połączeniu ze wspomnianymi wcześniej reakcjami ubocznymi, prowadzącymi do utworzenia nietrwałych nadtlenków, alkoholi, aldehydów i ketonów oraz reakcjami przerywania łańcucha reakcyjnego, prowadzącego do tworzenia produktów dimerycznych i polimerycznych, pokazują stopień skomplikowania zagadnienia zmian zachodzących w FAME w czasie wykonywania oznaczeń stabilności termooksydacyjnej.

Szybkość procesu utleniania zależy od ilości i położenia bis-alkilowej grupy metylenowej $\left(\mathrm{CH}_{2}\right)$ względem wiązania podwójnego w łańcuchu komponentu olefinowego (np. $-\mathrm{CH}=\mathrm{CH}-\mathrm{CH}_{2}-\mathrm{CH}=\mathrm{CH}-$ ). Polinienasycone estry metylowe są bardziej podatne na utlenianie niż mononienasycone estry, ponieważ zawierają więcej grup alkilowo-metylenowych [6, 12]. Stabilność oksydacyjna nie koreluje z całkowitą liczbą wiązań podwójnych, ale z całkowitą ilością bis-alkilowych grup [1]. Głównym produktem utleniania wiązań podwójnych są nadtlenki i allilowe hydronadtlenki [12]. Wodoronadtlenki są niestabilne i łatwo tworzą różne wtórne produkty utleniania. Wodoronadtlenki ulegają reakcjom: przegrupowania do produktów o podobnej masie cząsteczkowej, rozszczepienia do związków o krótszych łańcuchach (tj. aldehydów i kwasów) i dimeryzacji, dając związki o wyższych masach cząsteczkowych [13]. W wyniku dalszej degradacji produkty te tworzą cząsteczki o krótszych łańcuchach, do których zaliczamy kwasy, aldehydy, ketony i alkohole [1]. Dalsza reakcja niestabilnych hydronadtlenków z łańcuchem kwasu tłuszczowego może powodować dimeryzację lub trimeryzację w cząsteczki o wyższych masach cząsteczkowych $[3,4,8]$.
Innym aspektem, który może mieć istotny wpływ na całkowitą stabilność oksydacyjną biodiesla jest struktura izomerów cis/trans. Nienasycona struktura trans jest bardziej stabilna niż nienasycona struktura izomeru cis. Sprzężenie nienasycone trans jest bardziej wrażliwe na utlenianie niż nienasycona struktura cis [12].

Szybkość utleniania w mieszaninie naturalnych olejów roślinnych może się jednak różnić od czystych związków, ze względu na obecność substancji przyspieszających i spowalniających proces utleniana. Mnogość wielu, wtórnych produktów degradacji odzwierciedla to, jak bardzo skomplikowany jest proces rozkładu wodoronadtlenków. Te wtórne produkty mogą być sklasyfikowane jako monomery (produkty o tej samej długości łańcucha jak wyjściowy związek, różniący się od niego grupą funkcyjną), oligomery (produkty o wyższej masie cząsteczkowej) i produkty o krótszych łańcuchach. Podczas procesu rozkładu mogą mieć miejsce reakcje odwodnienia, cyklizacji, przegrupowania, podstawienia, podstawienia rodnika, rozszczepienia łańcucha, dimeryzacji itp. W wielu przypadkach ma miejsce kombinacja tych typów reakcji, co prowadzi lub przyczynia się do tworzenia wtórnych produktów utlenienia [13].

Produkty procesu wtórnego utleniania powstają w różnych ilościach i zależą od substratów (oleinian, linolan lub linolenian) [5]. Monomeryczne wtórne produkty utleniania obejmują związki karbonylowe, związki epoksydowe, di- i trihydroksyzwiązki, nadtlenki i wodoronadtlenki. Oligomeryczne, zazwyczaj otrzymane z kwasu linolowego lub linolenowego, obejmują dimery połączone poprzez grupę peroksykwasów lub eterów, jak również połączenia dimerów z wiązaniami C-C i oligomerów, składających się ze sprzężonych dimerów dienowych i trienowych wodoronadtlenków. Powstające substancje lotne obejmują różne krótsze nasycone i nienasycone aldehydy, jak również związki ketonowe oraz kwasy tłuszczowe o krótszym łańcuchu. Położenie grup funkcjonalnych w łańcuchu zależy głównie od położenia pierwotnych wiązań podwójnych, a zatem uzyskanych wodoronadtlenków [13].

Odporność na utlenianie estrów metylowych kwasów tłuszczowych można zwiększyć, stosując przeciwutleniacze naturalne i syntetyczne. Substancje te działają poprzez opóźnianie utleniania, ale nie zapobiegają temu procesowi. Ich celem jest przedłużenie wystąpienia reakcji inicjacji lub zmniejszenie długości propagacji. Antyutleniacze wiążą wolne rodniki i zatrzymują reakcje łańcuchowe. Rodniki tłuszczowe są stabilizowane i łańcuchowa reakcja utleniania jest przerwana. Przechowywanie paliwa bez dostępu tlenu zmniejsza lub eliminuje jego utlenianie i może zwiększyć długość magazynowania - może odbywać to się za pomocą wypełniania zbiorników paliwa azotem lub przechowywania estrów w szczelnych beczkach czy też pojemnikach o mniejszych objętościach; 
przeciwutleniacze, występujące naturalnie lub wprowadzone w formie dodatków, mogą poprawić stabilność oksydacyjną paliw.

Względy ochrony środowiska naturalnego oraz dywersyfikacja źródeł energii wymuszają coraz większy udział biokomponentów zawartych w paliwach węglowodorowych. Dodawane do olejów napędowych biokomponenty w postaci FAME podwyższają gęstość i lepkość paliwa, co ma istotny wpływ na pogorszenie jakości jego rozpylania w komorze spalania silnika. Dodatkowo, wyższe napięcie powierzchniowe FAME (B100) względem konwencjonalnego oleju napędowego $(\mathrm{ON})$ także przyczynia się do ogólnie gorszego rozdrobnienia kropel paliwa, a następnie ich rozproszenia i wymieszania $\mathrm{z}$ ładunkiem powietrza przed zainicjowaniem procesu spalania $[15,26]$.

Obecne wymagania stawiane olejom napędowym są w dużym stopniu związane z przeciwdziałaniem niekorzystnym zjawiskom tworzenia się osadów koksowych, zwłaszcza w obszarze otworków wylotowych i w kanalikach paliwowych rozpylaczy układów wtrysku paliwa. Na przykład, ograniczenie zawartości siarki do $350 \mathrm{mg} / \mathrm{kg}$, policyklicznych węglowodorów aromatycznych do $11 \%(\mathrm{~m} / \mathrm{m})$, stabilności oksydacyjnej oznaczonej według normy PN-EN 12205 do $25 \mathrm{~g} / \mathrm{m}^{3}$ czy zawartości FAME do 7\% (V/V) [24] zmniejsza tendencję paliwa do tworzenia przedmiotowych osadów podczas eksploatacji silników. W miarę rozwoju silników ZS okazało się, że wymagania normy EN 590 nie są wystarczające. Organizacja ACEA, powołana w UE do uregulowania wymagań w zakresie właściwości użytkowo-eksploatacyjnych paliw węglowodorowych, doprowadziła do powstania Światowej Karty Paliw (Worldwide Fuel Charter - WWFC) [30], która z powodzeniem, jak dotąd, systematyzuje i weryfikuje wymagania w zakresie jakości ustalonych kategorii olejów napędowych oraz benzyn silnikowych. Wprowadzono w niej, oprócz wymagań dotyczących właściwości fizykochemicznych wymienionych paliw, również testy laboratoryjne i silnikowe, łącznie z wymaganiami, których spełnienie gwarantuje bezpieczną i niezawodną eksploatację nowoczesnych silników. Spełnienie przez badane paliwa wymagań części testów laboratoryjnych oraz wszystkich silnikowych zależy od stosowania odpowiednich dodatków uszlachetniających [24].

Obecnie najistotniejsze wymagania stawiane przez WWFC olejom napędowym to zawartość policyklicznych węglowodorów aromatycznych, aromatów oraz siarki, stabilność termooksydacyjna i inne cechy, mające wpływ na jakość paliwa. Dodatkowo wprowadzone są tam też inne badania, takie jak: ocena smarności w teście HFRR czy badanie właściwości detergentowych w teście stanowiskowym z silnikiem Peugeot XUD 9 [24].

Procedura CEC F-23-01, dotycząca badania skłonności do zanieczyszczania rozpylaczy paliwa na silniku Peugeot XUD 9/A/L, została przygotowana $\mathrm{w}$ celu oceny jakości olejów napędowych, bez dodatków uszlachetniających i z pakietem dodatków, pod kątem ich skłonności do zakoksowania rozpylaczy wtryskiwaczy nowoczesnego (wówczas) silnika ZS z wtryskiem pośrednim. Skłonność badanego paliwa do zakoksowywania rozpylaczy wyraża się w postaci zmniejszenia strumienia powietrza (w procentach) przez rozpylacz przy wielkościach wzniosu iglicy $0,10 \mathrm{~mm}, 0,20 \mathrm{~mm}$ i $0,30 \mathrm{~mm}$. Obecnie obowiązujące wydanie Światowej Karty Paliw wymaga, aby w przypadku olejów napędowych kategorii 2 do 5 maksymalny spadek strumienia powietrza przez wtryskiwacz po przeprowadzonym teście XUD9 nie był większy niż $85 \%$, podczas gdy producenci paliw oczekują już spadku nie większego niż 60\%, a nawet niższego (poniżej 30\%) [23].

Jak już wspomniano, estry wyższych kwasów thuszczowych, dodawane w różnych proporcjach do konwencjonalnych olejów napędowych, stosunkowo szybko ulegają procesowi utleniania, tworząc różnego rodzaju osady, żywice, polimery, kwasy i inne zanieczyszczenia. Powstałe produkty utleniania prowadzą do zatykania filtrów, blokowania przepływów i degradacji elementów wykonanych z tworzywa i elastomerów. Dla oceny jakości paliwa w kontekście ww. problemów kluczowe znaczenie ma, poza szeroko już opisaną oceną stabilności oksydacyjnej, badanie ilości zanieczyszczeń, zarówno mechanicznych, jak i tych powstałych w trakcie utleniania się paliw. Stosowanie dokładnych filtrów paliwowych w układach paliwowych silników o zapłonie samoczynnym zapobiega w dość skuteczny sposób procesowi degradacji tych układów. Drobiny zanieczyszczeń mechanicznych oraz różnego rodzaju żele, będące produktami utleniania zwłaszcza biokomponentów, w dużej mierze zatrzymywane są w czasie przepływu paliwa przez filtry, zabezpieczające gładkie powierzchnie elementów pomp i wtryskiwaczy przed uszkodzeniem [20]. Głównym źródłem zanieczyszczeń paliw są:

- zanieczyszczenia produkcyjne z instalacji rafineryjnych,

- zanieczyszczenia powstałe w wyniku transportu w cysternach i przechowywania w zbiornikach stacji paliw,

- zanieczyszczenia dostające się z zewnątrz w trakcie napełniania układów lub w przypadku ich nieszczelności,

- zanieczyszczenia powstałe w wyniku wzajemnej współpracy elementów układu, tarcia, ciśnienia i temperatury, np. w trakcie przepompowywania paliwa,

- zanieczyszczenia powstałe w wyniku oddziaływania z uszczelnieniami oraz przewodami elastomerowymi,

- zanieczyszczenia powstałe w wyniku procesów utleniania w trakcie przechowywania,

- zanieczyszczenia związane z korozją i destrukcją powierzchni układów,

- zanieczyszczenia wytrącone w wyniku interakcji różnych składników paliwa, 
- brak kompatybilności paliwa z materiałem konstrukcyjnym układu paliwowego,

- produkty przemiany materii i obumierania mikroorganizmów. W okresie eksploatacji pojazdów mechanicznych zanieczyszczenia te osadzają się na filtrach, stopniowo zmniejszając przepływ paliwa do silnika, aż do całkowitego jego zablokowania. Tendencję paliw do blokowania filtrów mierzy się w celu ustalenia wpływu paliwa na czas użytkowania filtrów w pojazdach mechanicznych. Test ten zaczęto wprowadzać w odpowiedzi na problemy użytkowników pojazdów z blokującymi się filtrami paliwa, zwłaszcza w okresie eksploatacji pojazdów napędzanych paliwem z zawartością FAME. Zaobserwowano, że zwiększająca się zawartość FAME w paliwach do silników o zapłonie samoczynnym w istotny sposób wpływa na ograniczoną efektywność pracy filtrów paliwa (blokowanie) [20].

Prosimy cytować jako: Nafta-Gaz 2017, nr 5, s. 399-405, DOI: 10.18668/NG.2018.05.08

Artykuł nadesłano do Redakcji 24.11.2017 r. Zatwierdzono do druku 6.03.2018 r.

Artykuł powstał na podstawie pracy statutowej pt.: Opracowanie procedury kompleksowego badania efektywności dodatków przeciwutleniajacych stosowanych do FAME - praca INiG - PIB na zlecenie MNiSW; nr zlecenia: 0092/TE/17, nr archiwalny: DK-4100-/0079.

\section{Literatura}

[1] Araújo S.V., Luna F.M.T., Rola Jr E.M., Azevedo D.C.S., Cavalcante Jr C.L.: A rapid method for evaluation of the oxidation stability of castor oil FAME: Influence of antioxidant type and concentration. Fuel Processing Technology 2009, vol. 90, nr 10, s. $1272-1277$.

[2] Bouaid A., Martinez M., Aracil J.: Production of biodiesel from bioethanol and Brassica carinata oil: Oxidation stability study. Bioresource Technology 2009, vol. 100, nr 7, s. 2234-2239.

[3] Damasceno S.S., Santos N.A., Santos I.M.G., Souza A.L., Souza A.G., Queiroz N.: Caffeic and ferulic acids: An investigation of the effect of antioxidants on the stability of soybean biodiesel during storage. Fuel 2013, vol. 107, s. 641-646.

[4] Dantas M.B., Albuquerque A.R., Barros A.K., Rodrigues M.G., Antoniosi N.R., Sinfronio S.M., Rosenhaim R., Soledade L.E.B., Santos I.M.G., Souza A.G.: Evaluation of the oxidative stability of corn biodiesel. Fuel 2011, vol. 90, s. 773-778.

[5] de Carvalho A.L., Cardoso E.A., da Rocha G.O., Teixeira L.S.G., Pepe I.M., Grosjean D.M.: Carboxylic acid emissions from soybean biodiesel oxidation in the EN14112 (Rancimat) stability test. Fuel 2016, vol. 173, s. 29-36.

[6] Dodos G.S., Zannikos F., Stournas S.: Effect of metals in the oxidation stability and lubricity of biodiesel. SAE International 2009, s. 1-8.

[7] Dunn R.O.: Antioxidants for improving storage stability of biodiesel. Biofuels, Bioproducts and Biorefining 2008, vol. 2, nr 4, s. 304-318.

[8] Focke W.W., Westhuizen I.V.D., Grobler A.B.L., Nshoane K.T., Reddy J.K., Luyt A.S.: The effect of synthetic antioxidants on the oxidative stability of biodiesel. Fuel 2012, vol. 94, s. 227-233.

[9] Hoshino T., Iwata Y., Koseki H.: Oxidation stability and risk evaluation of biodiesel. Thermal Science 2007, vol. 11, nr 2, s. $87-100$.

[10] Jain S., Sharma M.P.: Stability of biodiesel and its blends: A review. Renewable and Sustainable Energy Reviews 2010, vol. 14, s. 667-678.

[11] Karavalakis G., Karonis D., Stournas S.: Evaluation of the oxidation stability of diesel/biodiesel blends using the modified method. SAE Int. J. Fuels Lubr. 2009, vol. 2, nr 1, s. 839-849, DOI: $10.4271 / 2009-01-1828$.

[12] Knothe G.: Dependence of biodiesel fuel properties on the structure of fatty acid alkyl esters. Fuel Processing Technology 2005, vol. 86, nr 10, s. 1059-1070.

[13] Knothe G.: Some Aspects of biodiesel oxidative stability. Fuel Processing Technology 2007, nr 88, s. 669-677.
[14] Krasodomski W., Żółty M.: Porównanie standardowych metod oznaczania stabilności oksydacyjnej olejów napędowych zawierajacych FAME. Nafta-Gaz 2017, nr 6, s. 422-429, DOI: 10.18668/NG.2017.06.07.

[15] Lauterwasser F.: Development of high performance heavy duty engine oils. Materiały Chevron Oronite LLC, 6.08.2009.

[16] Ouigley R.: Biodiesel: The good, the bad... and additives. Biofuels International 2007, vol. 1, s. 70-72.

[17] Pullen J., Saeed K.: An overview of biodiesel oxidation stability. Renewable and Sustainable Energy Reviews 2012, vol. 16, nr 8, s. 5924-5950.

[18] Pullen J., Saeed K.: Experimental study of the factors affecting the oxidation stability of biodiesel FAME fuels. Fuel Processing Technology 2014, vol. 125, s. 223-235.

[19] Rizwanul I.M. Fattah, Masjuki H.H., Kalam M.A., Hazrat M.A., Masum B.M., Imtenan S., Ashraful A.M.: Effect of antioxidants on oxidation stability of biodiesel derived from vegetable and animal based feedstocks. Renewable and Sustainable Energy Reviews 2014, vol. 30, s. 356-370.

[20] Sacha D.: Nowoczesne narzędzia badawcze do oceny właściwości użytkowych paliw do silników o zapłonie samoczynnym. Nafta-Gaz 2012, nr 2, s. 133-138.

[21] Shashi Kant Bhatia, Ravi Kant Bhatia, Yung-Hun Yang: An overview of microdiesel - A sustainable future source of renewable energy. Renewable and Sustainable Energy Reviews 2017, vol. 79, s. 1078-1090.

[22] Stability of Biodiesel - Used as a fuel for diesel engines and heating systems. Presentation of the BIOSTAB project results. Proceedings. Graz, July $3^{\text {rd }}, 2003$. Published by BLT Wieselburg, Austria 2003.

[23] Stępień Z.: Ewolucja metodyki oceny zanieczyszczenia rozpylaczy silników o zapłonie samoczynnym. Nafta-Gaz 2014, nr 10, s. 707-717.

[24] Stępień Z., Żak G., Wojtasik M., Ziemiański L.: Problemy zwiazane z tworzeniem się osadów na elementach układów wtryskowych nowoczesnych silników Diesla - przyczyny, metody badań, przeciwdziałanie. Nafta-Gaz 2013, nr 9, s. 702-709.

[25] Tang H., Abunasser N., Wang A., Clark B.R., Wadumesthrige K., Zeng S., Kim M., Salley S.O., Hirschlieb G., Wilson J., NG K.Y.S.: Quality survey of biodiesel blends sold at retail stations. Fuel 2008, vol. 87, nr 13-14, s. 2951-2955.

[26] Urzędowska W., Stępień Z.: Olej silnikowy a biopaliwa - wspótdziałanie w eksploatacji. Nafta-Gaz 2010, nr 10, s. 914-922.

[27] Urzędowska W., Stępień Z.: Prediction of threats caused by 
high FAME diesel fuel blend stability for engine injector operation. Fuel Processing Technology 2016, vol. 142, s. 403-410.

[28] Van Gerpen J., Shanks B., Pruszko R., Clements D., Knothe G.: Biodiesel analytical methods. Subcontractor report. National Renewable Energy Laboratory 2004, NREL/SR-510-36244.

[29] Westbrook S.R.: An evaluation and comparison of test methods to measure the oxidation stability of neat biodiesel. Subcontractor report. National Renewable Energy Laboratory, NREL/ SR-540-38983.
[30] Worldwide Fuel Charter, Fifth Edition, September 2013, http://www.acea.be/uploads/publications/Worldwide_Fuel_ Charter_5ed_2013.pdf(dostęp: 27.10.2017).

[31] Zeyu Yang, Hollebone B.P., Zhendi Wang, Chun Yang, Landriault M.: Factors affecting oxidation stability of commercially available biodiesel products. Fuel Processing Technology 2013, vol. 106, s. 366-375.
Dr inż. Magdalena ŻÓŁTY

Adiunkt w Zakładzie Oceny Właściwości Eksploatacyjnych; kierownik Laboratorium Badań Właściwości Użytkowych.

Instytut Nafty i Gazu - Państwowy Instytut Badawczy ul. Lubicz 25 A, 31-503 Kraków

E-mail: magdalena.zolty@inig.pl

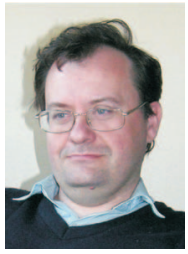

Dr Wojciech KRASODOMSKI

Adiunkt; kierownik Laboratorium Analiz Dodatków. Instytut Nafty i Gazu - Państwowy Instytut Badawczy ul. Lubicz 25 A

31-503 Kraków

E-mail:wojciech.krasodomski@inig.pl

\section{OFERTA}

\section{ZAKŁAD OCENY WŁAŚCIWOŚCI EKSPLOATACYJNYCH}

\section{Zakres działania:}

- $\quad$ ocena w testach laboratoryjnych właściwości fizykochemicznych oraz użytkowo-eksploatacyjnych wg najnowszych procedur badawczych, zarówno europejskich, jak i amerykańskich:

» paliw ciekłych, biopaliw i biokomponentów,

» środków smarowych, w tym: olejów silnikowych, przekładniowych i przemysłowych, zarówno świeżych, jak i przepracowanych;

- $\quad$ pełny zakres usług w zakresie nowoczesnego planowania i monitorowania właściwości olejów smarowych w eksploatacji wraz z ocena zachodzacych w nich zmian, doradztwo i ekspertyzy w zakresie użytkowania olejów niewłaściwej jakości lub ich niewłaściwej eksploatacji;

- $\quad$ szeroki zakres ocen stanowiskowych właściwości trybologicznych paliw, środków smarowych oraz cieczy hydraulicznych

- oceny liczb oktanowych i cetanowych $w$ testach silnikowych wg procedur europejskich i amerykańskich;

- jedyne w kraju oceny właściwości użytkowo-eksploatacyjnych paliw silnikowych wg ogólnoeuropejskich testów silnikowych opracowanych przez CEC i wymaganych między innymi przez Worldwide Fuel Charter;

- oceny kompatybilności dodatków do paliw i olejów smarowych, usługi eksperckie w zakresie problemów związanych z niekompatybilnością wymienionych produktów w eksploatacji;

- $\quad$ oceny właściwości użytkowo-eksploatacyjnych paliw i olejów smarowych w badaniach eksploatacyjnych;

- $\quad$ usługi eksperckie w zakresie wpływu jakości paliw na możliwości powstania dysfunkcji i uszkodzeń silnikowych układów wtrysku paliwa;

- badania procesów regeneracji filtrów cząstek stałych na stanowisku silnikowym, doradztwo w zakresie eksploatacji układów filtracji spalin wyposażonych w filtry cząstek stałych.

Kierownik: dr inż. Zbigniew Stępień

Adres: ul. Łukasiewicza 1, 31-429 Kraków

Telefon: 126177578

Faks: 126177522

E-mail: zbigniew.stepien@inig.pl 